
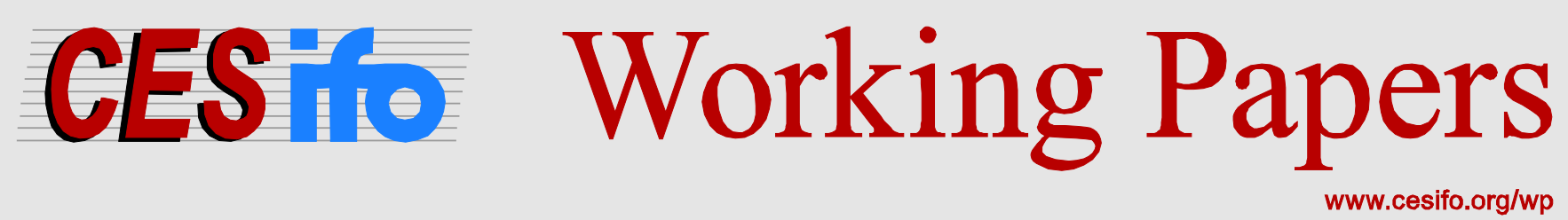

\title{
Trust in Government and Fiscal Adjustments
}

\author{
Dirk Bursian \\ Alfons J. Weichenrieder \\ Jochen Zimmer
}

\author{
CESIFO WORKING PAPER NO. 4310 \\ CATEgory 6: Fiscal Policy, Macroeconomics and Growth \\ JUNE 2013
}
An electronic version of the paper may be downloaded
- from the SSRN website: Www.SSRN.com
- from the RePEc website: Www.RePEc.org
- from the CESifo website: www.CESifo-group.org/wp

\section{CESifo}




\title{
Trust in Government and Fiscal Adjustments
}

\begin{abstract}
The paper looks at the determinants of fiscal adjustments as reflected in the primary surplus of countries. Our conjecture is that governments will usually find it more attractive to pursue fiscal adjustments in a situation of relatively high growth, but based on a simple stylized model of government behavior the expectation is that mainly high trust governments will be in a position to defer consolidation to years with higher growth. Overall, our analysis of a panel of European countries provides support for this expectation. The difference in fiscal policies depending on government trust levels may help explaining why better governed countries have been found to have less severe business cycles. It suggests that trust and credibility play an important role not only in monetary policy, but also in fiscal policy.
\end{abstract}

JEL-Code: H620, E620.

Keywords: trust, debt sustainability, fiscal reaction function, euro area, EU.

Dirk Bursian

Goethe University Frankfurt

Germany - 60323 Frankfurt (Main)

Dirk.Bursian@hof.uni-frankfurt.de
Alfons J. Weichenrieder

Goethe University Frankfurt

Faculty of Economics and Business

Administration

Germany - 60323 Frankfurt (Main)

a.weichenrieder@em.uni-frankfurt.de

\author{
Jochen Zimmer \\ Goethe University Frankfurt \\ Germany - 60323 Frankfurt (Main) \\ jzimmer@wiwi.uni-frankfurt.de
}

04 June 2013

Alfons Weichenrieder is also affiliated with the University of Economics and Business, Vienna, and CESifo. We thank Jeremy Edwards, Robert Krämer and participants of the DG-R Seminar of the ECB for very helpful comments. The paper is part of the research program of the Center "Sustainable Architecture for Finance in Europe" (S A F E). Jochen Zimmer gratefully acknowledges financial support by Hanns-Seidl-Stiftung. 


\section{Introduction}

When it comes to the private exchange of goods and services, trust in cooperative behavior by trading partners can reduce transaction costs and increase the benefits of comparative advantage. In recent economic research, the amount of trust in society has been identified as an important factor that benefits economic performance and growth (see, for instance, Zak and Knack, 1999, and Knack and Keefer, 1997).

It is not only private agents who may benefit from being trusted but also governments. Trust in government may allow more delegation of political decisions and may make redundant tight decision rules that, while serving as a potentially helpful commitment, can produce a cost due to the inflexibility that they introduce. A frequently used example of how trust can increase flexibility is the 'only Nixon could go to China' phenomenon. Public trust in the conservative political ideals of Nixon allowed him a pragmatic approach towards a communist country that would not have been possible for a liberal president.

While reciprocal trust is an active area of research (see, for instance, Sapienza and Zingales, 2011, Alesina and La Ferrara, 2002, and La Porta et al., 1997), it seems that less research has been done to assess the role of trust in government or political institutions. Of course some exceptions apply. The concept of trust has recently received attention in the literature on tax evasion (Feld and Frey, 2002). Perhaps more prominently, Kydland and Prescott (1977), Barro and Gordon (1983), and Rogoff (1985) emphasize that a high level of credibility and reputation, concepts which are inherently related to trust, increases the efficiency of policy actions in the context of monetary policy. In this respect, Bursian and Fürth (2012) are among the first to examine individual as well as macroeconomic factors that influence trust in the European Central Bank using micro data. Furthermore, Bursian and Faia (2013) use microfoundations of trust and implement trust in the monetary authority into a dynamic macro model.

As in the area of monetary policy, we expect trust to play a prominent role also in the context of fiscal policy. Fiscal reputation and trust in the prudence of the political process 
may give a government important leeway when reacting to fiscal shocks. While a government that lacks trust may find itself pressed to firmly react to a shock in the debt level by increasing taxes and reducing expenditures, a highly trusted government can possibly defer fiscal corrections to a later period when the macroeconomic situation is more suitable and the cost of austerity is less severe. The ongoing debt crisis in European countries may come to mind, but recently such an argument has been made for the U.S. as well. In a Wall Street Journal article (Hilsenrath, 2013), the decline in trust has recently been named as a possible reason that prevented the U.S. government from pursuing stronger counter-cyclical measures during the financial crisis.

Trust also seems to be important when it comes to voters' preferences towards fiscal policies. In a recent study using a large representative survey of German voters, Heinemann and Henninghausen (2012) find that respondents with a high level of trust have a stronger preference for low deficits than respondents with a low trust in government.

Motivated by these findings and conjectures, the present paper studies the relation between citizens' trust in the national government on the one hand and observed fiscal behavior on the other hand. To do so we exploit data for the European Union (EU) covering the years 1999 to 2011. Since 1999, the Eurobarometer surveys conducted on behalf of the European Commission have a regular question on trust in public institutions, which allows the analysis of an extensive country panel. We use this information on general trust towards national governments by estimating fiscal reaction functions as presented, for instance, in Bohn (1998), and Mendoza and Ostry (2008). Our findings support the idea that the level of trust in government has implications for fiscal policy and more specifically for the development of primary budget deficits. Our findings are compatible with the view that a high level of trust increases the leeway of governments and allows more expansionary policies during periods when the economy is weak. As in previous estimates of fiscal reaction functions, we find that the higher the debt level, the higher is the targeted primary surplus of a country. At the same time, we find evidence that a high level of trust leads to smaller fiscal corrections in times when growth is low. 
The organization of the paper is the following. Section 2 presents a simple stylized model of trust and primary surpluses. Section 3 presents the data sources and descriptive statistics. Empirical results are discussed in section 4 and section 5 concludes.

\section{A simple theoretical framework}

Based on the simple arithmetic of the intertemporal budget constraint of the government, the inherited amount of public debt requires an equally large amount of discounted primary surpluses in the future. Therefore, an increase in the stock of debt due to some shock is expected to lead to an increased primary surplus. While a reaction is necessary to comply with the budget constraint, the exact timing may be debatable and the current macroeconomic situation may be crucial. Recent empirical research suggests that fiscal multipliers indeed are comparatively larger if the economy shows low utilization of resources (Auerbach and Gorodnichenko, 2012a, 2012b). Increasing the primary surplus in times of fully-utilized capacity may therefore be less costly than pursuing a fiscal correction in times of a flat economy.

This idea may be spelled out by assuming that the government is minimizing a loss function $L$ that has several components. The component $\sigma(p)$ reflects the positive and convex cost of having a primary surplus $p$. This cost is increasing in $p$ as governments are assumed to prefer spending over a strict consolidation policy. Since trust in government has been shown to be associated with voters' preference for lower deficits (Heinemann and Henninghausen, 2012) we weigh this cost component by the term $(1-t)$, where $0 \leq t \leq 1$ is a measure of trust in government. As a consequence, other things equal, trusted governments have a higher concern for the future and hence a smaller preference for high deficits. Another consideration comes from the size of debt levels. High debt levels may make fiscal corrections inevitable so we assume a convex function $\delta(p \cdot d)$ that enters negatively in the loss function, where $d$ captures the debt level which is non-negative by assumption. Hence, this sub-function $\delta$ and the multiplicative interaction of $p$ and $d$ imply that a given primary surplus provides a larger benefit if the debt level is high as the need for a high primary surplus is more pressing. 
Finally, to capture the inconvenience of fiscal corrections in times of low capacity usage, i.e. a cyclical downturn, we add the convex cost $\gamma(p \cdot g)$, where $g>0$ is a measure of the underutilization of production capacity. This cost component captures the idea that fiscal adjustments have different multiplier effects dependent on the state of the economy.

Taking together the three components of the imposed loss function, we have the function

$$
L=\sigma(p)(1-t)-\delta(p \cdot d)+\gamma(p \cdot g)
$$

that the government aims to minimize. We assume that the debt levels and surpluses are normalized such that their values are positive throughout. Similar to loss functions that are usually assumed for monetary policy, we propose a quadratic form of the additive parts, which implies, together with the non-negativity assumptions of $p, d$, and $g$,

$$
\begin{aligned}
& \sigma^{\prime}(p), \delta^{\prime}(p \cdot d), \gamma^{\prime}(p \cdot g) \geq 0 \\
& \sigma^{\prime \prime}(p), \delta^{\prime \prime}(p \cdot d), \gamma^{\prime \prime}(p \cdot g)>0 \\
& \sigma^{\prime \prime \prime}(p)=\delta^{\prime \prime \prime}(p \cdot d)=\gamma^{\prime \prime \prime}(p \cdot g)=0 .
\end{aligned}
$$

From the first order condition of the government we have that

$$
\partial L / \partial p=\sigma^{\prime}(p) \cdot(1-t)-\delta^{\prime}(p \cdot d) \cdot d+\gamma^{\prime}(p \cdot g) \cdot g=0
$$

Making use of the second order condition for a minimum $\left(\sigma^{\prime \prime}(p) \cdot(1-t)-\delta^{\prime \prime}(p \cdot d) \cdot d^{2}+\right.$ $\left.\gamma^{\prime \prime}(p \cdot g) \cdot g^{2}>0\right)$, total differentiation of this first order condition implies that

$$
\frac{\mathrm{d} p}{\mathrm{~d} d}>0
$$

A higher level of debt implies an increase in the optimal level of the surplus. This is what we would also expect from an intertemporal budget constraint. From the first order condition (3) and assumption (2) we obtain

$$
\frac{\mathrm{d} p}{\mathrm{~d} g}<0
$$


Hence, the desired magnitude of the primary surplus is smaller when capacities are weakly utilized. From taking the differential of (5) with respect to the debt level $d$ we obtain

$$
\frac{\mathrm{d}^{2} p}{\mathrm{~d} d \mathrm{~d} g}<0
$$

From (6) we find that the fiscal correction triggered by a change in debt will be smaller if capacities are underutilized, i.e. if $g$ is larger. Finally, we find from taking the derivative of (6) with respect to $t$ that

$$
\frac{\mathrm{d}^{3} p}{\mathrm{~d} g \mathrm{~d} d \mathrm{~d} t}<0
$$

From (7) we derive that a high trust government will in general have smaller fiscal reactions upon a shock in debt than a low trust government.

We may summarize our expectations from equations (4) to (7) in

Proposition 1: (i) The higher the debt level, the higher is the targeted primary surplus. (ii) This primary surplus is smaller if macroeconomic capacities are underutilized. (iii) High trust governments react differently from low trust governments and have a smaller correction of the primary surplus upon a shock in the debt level when macroeconomic capacities are less than fully utilized.

\section{Data sources and descriptive statistics}

Eurobarometer surveys, which are conducted on behalf of the European Commission, usually appear twice a year and cover all EU member countries. Among other things, the surveys ask participants about their trust in several institutions. One question is specifically on national governments as one of the institutions covered: 
"I would like to ask you a question about how much trust you have in certain institutions. For each of the following institutions, please tell me if you tend to trust it or tend not to trust it. (READ OUT) The (NATIONALITY) Government”

Survey participants are given the choice between three possible answers: "1, Tend to trust", “2, Tend not to trust", and "3, Do not know".

The binary measure of trust is transformed into a continuous variable by calculating the fraction of respondents that tend to trust the government. We average the biannual data into yearly data to obtain an annual panel from 1999 to 2011 . A detailed description of the data source can be found in the appendix. Figure 1 presents the mean response regarding trust in national governments from 1999 to 2011 for the EU and the euro area. The data shows a substantial variation of the average levels of trust over time. Table 1 contains the responses for all countries and available years and also illustrates the substantial variation across countries. In the starting year 1999, the lowest level of trust in national governments was recorded for Belgium (.251) and the highest level of trust for Luxembourg (.710). After 2008, the level of trust in national governments dropped substantially in many countries under consideration, with the lowest level (.09) reached in Latvia 2009.

An alternative potential measure of trust in government is the sovereign credit rating by international rating agencies. We prefer the survey based trust measure since country ratings are much more dependent on the level of government debt, a variable that we rather prefer to keep separate in the following empirical estimations. 
Figure 1: Average EU/euro area citizens' trust in national governments

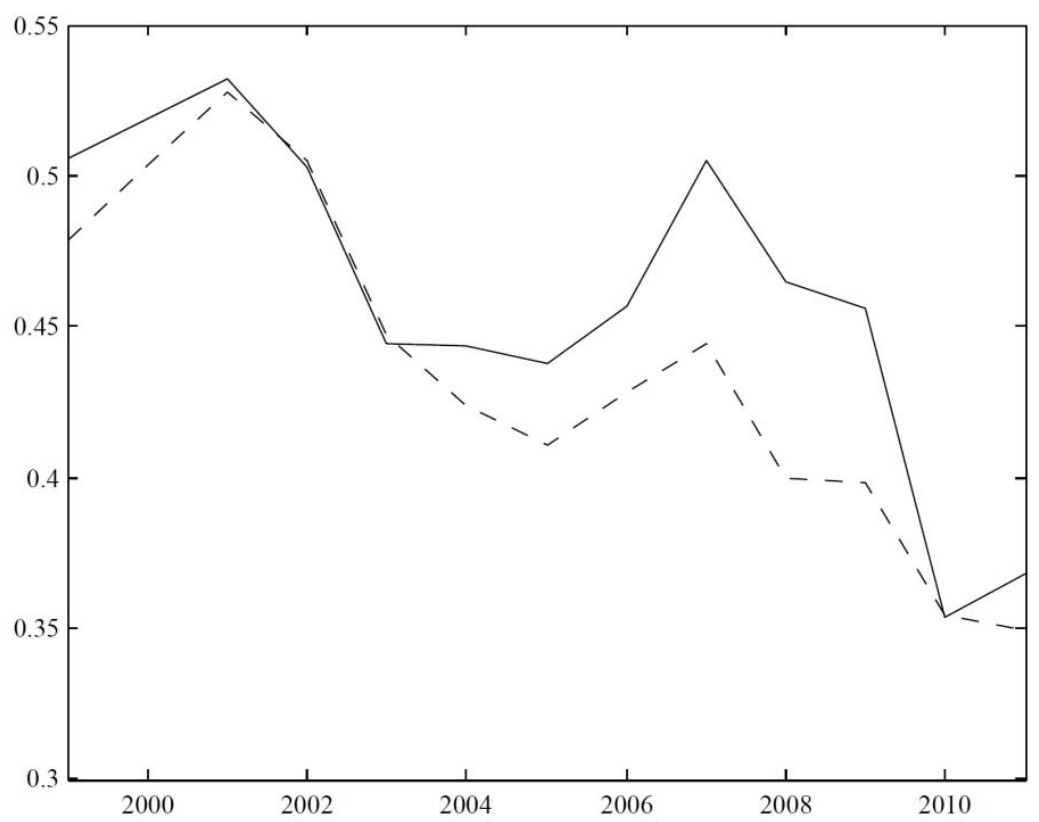

Notes: The figure presents the average (unweighted) country levels of EU (dashed)/euro area (solid) citizens' trust in national governments from 1999 to 2011 . Countries are included in the average for a given year if in this year they were a member of the EU or the euro area, respectively. The data for 2000 corresponds to the average value of 1999 and 2001 as no survey data on trust in national governments is available for that year.

\section{Figure 2: Average EU/euro area primary surplus in percent of GDP}

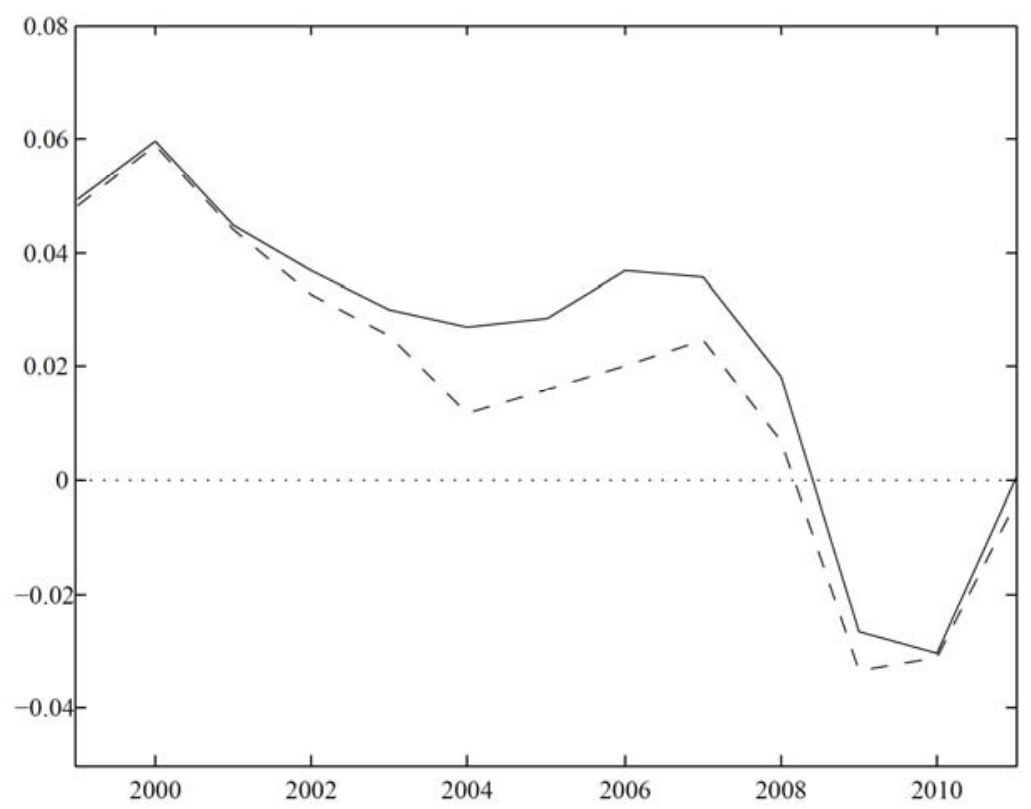

Notes: The figure presents the average (unweighted) country levels of EU (dashed)/euro area (solid) primary surplus in percent of GDP from 1999 to 2011. Countries are included in the average for a given year if in this year they were a member of the EU or the euro area, respectively. 
Our macroeconomic data includes information on total public debt and primary fiscal balances as shares of GDP, real GDP, and total government expenditures. The primary fiscal balances are calculated as the fiscal balance net of interest payments on public debt. We use data from the OECD's Analytical Database on general government gross financial liabilities and the government deficit/surplus as a share of GDP as well as on real GDP at current prices and on total expenditure of general government. For the gross government interest payments, we use data from the OECD Economic Outlook database. Figures 2 and 3 present the EU/euro area average primary surplus and indebtedness in percent of GDP. While on average the euro area countries had higher primary surpluses, they also had a higher average indebtedness.

Prior to 2008, the average EU/euro area debt ratios show a stable or even declining trend and similar things may be said for primary surpluses. From 2009, we see a stark increase in debt levels and strongly reduced primary surpluses. 
Table 1: Average level of trust in national governments

\begin{tabular}{|c|c|c|c|c|c|c|c|c|c|c|c|c|c|c|}
\hline Year & 1999 & 2000 & 2001 & 2002 & 2003 & 2004 & 2005 & 2006 & 2007 & 2008 & 2009 & 2010 & 2011 & Total \\
\hline Austria & 0.555 & 0.525 & 0.495 & 0.525 & 0.450 & 0.470 & 0.476 & 0.550 & 0.604 & 0.510 & 0.617 & 0.531 & 0.577 & 0.530 \\
\hline Belgium & 0.251 & 0.375 & 0.499 & 0.490 & 0.439 & 0.382 & 0.461 & 0.493 & 0.541 & 0.373 & 0.384 & 0.265 & 0.383 & 0.410 \\
\hline Bulgaria & & & & & & & & & 0.224 & 0.178 & 0.290 & 0.428 & 0.373 & 0.298 \\
\hline Cyprus & & & & & & 0.717 & 0.693 & 0.634 & 0.632 & 0.758 & 0.644 & 0.472 & 0.401 & 0.619 \\
\hline Czech Republic & & & & & & 0.301 & 0.242 & 0.310 & 0.238 & 0.199 & 0.290 & 0.294 & 0.148 & 0.253 \\
\hline Denmark & 0.437 & 0.517 & 0.598 & 0.600 & 0.594 & 0.536 & 0.588 & 0.570 & 0.648 & 0.593 & 0.623 & 0.450 & 0.484 & 0.557 \\
\hline Estonia & & & & & & 0.501 & 0.541 & 0.585 & 0.685 & 0.554 & 0.448 & 0.557 & 0.539 & 0.551 \\
\hline Finland & 0.612 & 0.605 & 0.599 & 0.587 & 0.597 & 0.650 & 0.666 & 0.652 & 0.685 & 0.642 & 0.576 & 0.500 & 0.605 & 0.613 \\
\hline France & 0.398 & 0.406 & 0.415 & 0.320 & 0.390 & 0.313 & 0.244 & 0.230 & 0.425 & 0.310 & 0.312 & 0.259 & 0.263 & 0.330 \\
\hline Germany & 0.463 & 0.466 & 0.469 & 0.415 & 0.299 & 0.279 & 0.272 & 0.322 & 0.445 & 0.394 & 0.450 & 0.318 & 0.371 & 0.382 \\
\hline Greece & 0.365 & 0.409 & 0.452 & 0.410 & 0.468 & 0.559 & 0.430 & 0.434 & 0.449 & 0.292 & 0.336 & 0.236 & 0.126 & 0.382 \\
\hline Hungary & & & & & & 0.448 & 0.374 & 0.401 & 0.267 & 0.173 & 0.178 & 0.495 & 0.326 & 0.333 \\
\hline Ireland & 0.438 & 0.476 & 0.513 & 0.471 & 0.355 & 0.437 & 0.422 & 0.412 & 0.408 & 0.383 & 0.233 & 0.159 & 0.356 & 0.390 \\
\hline Italy & 0.316 & 0.358 & 0.400 & 0.385 & 0.344 & 0.303 & 0.328 & 0.360 & 0.341 & 0.227 & 0.299 & 0.266 & 0.203 & 0.318 \\
\hline Latvia & & & & & & 0.288 & 0.354 & 0.302 & 0.205 & 0.175 & 0.090 & 0.170 & 0.175 & 0.220 \\
\hline Lithuania & & & & & & 0.418 & 0.284 & 0.256 & 0.272 & 0.180 & 0.171 & 0.144 & 0.168 & 0.236 \\
\hline Luxembourg & 0.710 & 0.744 & 0.778 & 0.756 & 0.696 & 0.712 & 0.749 & 0.715 & 0.733 & 0.645 & 0.786 & 0.717 & 0.780 & 0.732 \\
\hline Malta & & & & & & 0.549 & 0.504 & 0.494 & 0.553 & 0.588 & 0.493 & 0.403 & 0.428 & 0.501 \\
\hline Netherlands & 0.669 & 0.689 & 0.708 & 0.648 & 0.432 & 0.395 & 0.403 & 0.472 & 0.628 & 0.600 & 0.596 & 0.497 & 0.529 & 0.559 \\
\hline Poland & & & & & & 0.136 & 0.139 & 0.204 & 0.197 & 0.247 & 0.230 & 0.312 & 0.312 & 0.222 \\
\hline Portugal & 0.651 & 0.589 & 0.527 & 0.517 & 0.442 & 0.327 & 0.350 & 0.364 & 0.399 & 0.339 & 0.339 & 0.202 & 0.230 & 0.406 \\
\hline Romania & & & & & & & & & 0.217 & 0.265 & 0.281 & 0.125 & 0.120 & 0.202 \\
\hline Slovakia & & & & & & 0.223 & 0.199 & 0.322 & 0.455 & 0.446 & 0.456 & 0.386 & 0.288 & 0.347 \\
\hline Slovenia & & & & & & 0.408 & 0.410 & 0.417 & 0.362 & 0.360 & 0.377 & 0.233 & 0.132 & 0.337 \\
\hline Spain & 0.504 & 0.518 & 0.532 & 0.509 & 0.425 & 0.496 & 0.453 & 0.478 & 0.549 & 0.547 & 0.398 & 0.215 & 0.209 & 0.449 \\
\hline Sweden & 0.369 & 0.454 & 0.540 & 0.587 & 0.480 & 0.482 & 0.345 & 0.439 & 0.511 & 0.526 & 0.615 & 0.639 & 0.638 & 0.510 \\
\hline United Kingdom & 0.442 & 0.418 & 0.395 & 0.360 & 0.299 & 0.272 & 0.347 & 0.290 & 0.334 & 0.281 & 0.245 & 0.295 & 0.280 & 0.328 \\
\hline Total & 0.479 & 0.503 & 0.528 & 0.505 & 0.447 & 0.424 & 0.411 & 0.428 & 0.445 & 0.399 & 0.398 & 0.354 & 0.350 & 0.436 \\
\hline
\end{tabular}

Notes: The table presents the average level of EU/euro area citizens' trust in national governments from 1999 to 2011 . Countries are included in the average for a given year if in this year they were a member of the EU. The values for 2000 correspond to the average value of 1999 and 2001 as no survey data on trust in national governments is available for that year. 
Figure 3: Average EU/euro area indebtedness in percent of GDP

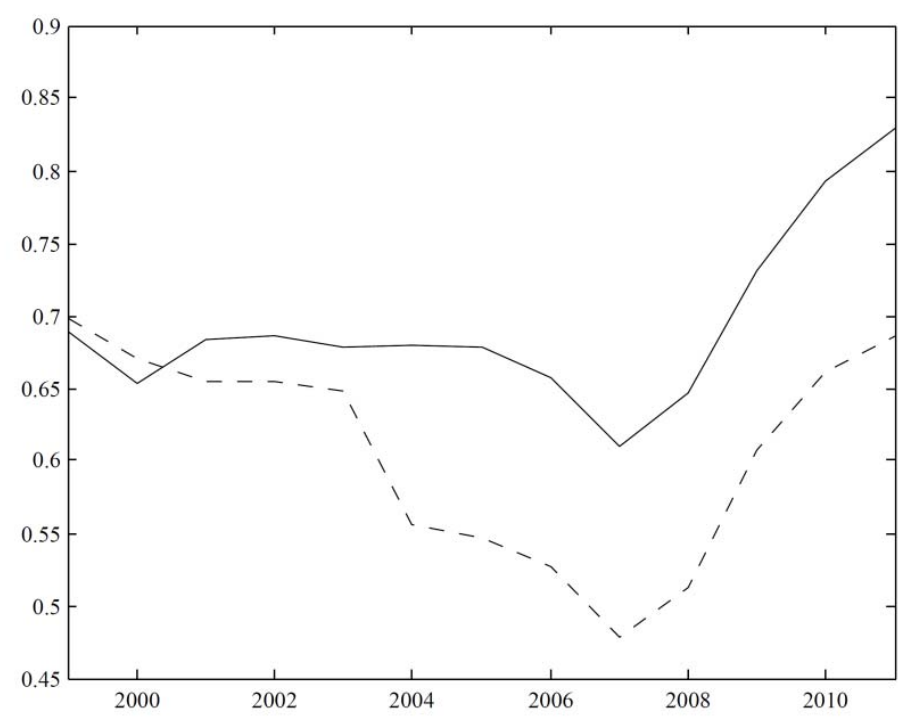

Notes: The figure presents the (unweighted) average EU (dashed)/euro area (solid) indebtedness as a fraction of GDP from 1999 to 2011. Countries are included in the average for a given year if in this year they were a member of the EU or the euro area, respectively.

\section{Empirical implementation and results}

We examine whether differences in the level of trust in the fiscal authority within EU and euro area countries are associated with different fiscal reactions to changes in debt. We do so by estimating a cross-country panel version of Bohn's (1998) "model-based sustainability approach" (MBSA). The MBSA analyzes how the primary deficit reacts to variations in the public debt caused by economic shocks. From the intertemporal budget constraint of the government an increase in the stock of debt must be accompanied with an increase of the discounted value of future primary surpluses. Although there is no necessity to react to a shock in debt right away, the observation of a positive immediate reaction is a sign that the 
government is respecting its intertemporal budget constraint. ${ }^{1}$ In the simplest and most common version, the MBSA assumes a linear connection between the inherited debt level and the primary surplus of period $t$

$$
s_{t}=\rho \cdot d_{t-1}+\mu_{t}
$$

where $s_{t}$ is the primary surplus as a fraction of GDP in period $t, d_{t-1}$ is the initial debt level relative to GDP, $\rho$ is an estimable coefficient, and $\mu_{t}$ represents factors other than the debt level relative to GDP which influence the primary surplus. Based on our expectations of how trust in government influences fiscal policy, we estimate a refined cross-country panel version of the MBSA:

$$
s_{i, t}=\beta_{1} d_{i, t-1}+\beta_{2} d_{i, t-1} * G D P_{-} G_{i, t}+\beta_{3} d_{i, t-1} * G D P_{-} G_{i, t} * \text { Trust }_{i, t-1}+\alpha V_{i, t}+\varepsilon_{i, t} .
$$

$S_{i, t}$ represents the primary surplus of country $i$ in year $t, G D P_{-} G_{i, t}$ is the percentage deviation of output from its trend value ${ }^{2}$, and $\varepsilon_{i, t}$ represents an error term with mean zero. $V_{i, t}$ is a vector of control variables that includes $G D P_{-} G_{i, t}$ (without interactions) and a measure of the deviation of government expenditure from its trend $\left(\operatorname{Exp}_{i, t}\right)$ as it is usually done in the associated literature (Bohn, 1998; Mendoza and Ostry, 2008) in order to capture shocks to countries' expenditure needs. Owing to the inclusion of various interaction terms, $V_{i, t}$ also includes separate elements of the interaction terms $\left(G D P_{-} G_{i, t},\left(G D P_{-} G_{i, t} *\right.\right.$ Trust $\left._{i, t-1}\right)$, $\left(d_{i, t-1} *\right.$ Trust $\left._{i, t-1}\right), \quad$ and Trust $\left._{i, t-1}\right)$ to ensure interpretability of the estimated coefficients.

\footnotetext{
${ }^{1}$ In contrast to earlier sustainability tests (see, for instance, Wilcox, 1989, Kremers, 1989, Haug, 1990, Hakkio and Rush, 1991, or Trehan and Walsh, 1991), the MBSA does not require assumptions about the appropriate discount factor. In addition, the MBSA lacks information requirements on debt structure or the design of fiscal policy.

${ }^{2}$ A Hodrick-Prescott filter with a standard annual smoothing parameter of $\lambda=100$ has been applied.
} 
The results of our empirical model allow for a direct comparison with the predictions of the theoretical expectations spelled out in Proposition 1. The coefficients of particular interest are $\beta_{1}$ and $\beta_{3}$. When interpreting the results, keep in mind that the variable GDP_G, which measures the relative deviation of output from the relevant country trend, is inversely related to the underutilization of production capacities as captured by the variable $g$ in section 2. The coefficient $\beta_{1}$ tends to indicate whether the primary surplus reacts systematically to variations in the lagged debt to GDP ratio. From the requirements of the intertemporal budget constraint, we should expect a positive correlation between debt and primary surpluses. However, the overall effect of debt works not only through $\beta_{1}$, but also through the interaction terms that include our debt measure. We expect that the extent to which high debt levels lead to increases in primary surpluses will depend on the macroeconomic situation. In general, consolidation, i.e. a high primary surplus, should be more palatable in years with fast growth, while years with mediocre growth performance will tempt governments to postpone consolidation and to wait for a more suitable time. At the same time, only high trust governments may be able to do so, while low trust governments may feel obliged to consolidate irrespective of the macroeconomic situation. To capture this idea of different reactions econometrically, we include the interaction term $d_{i, t-1} * G D P_{-} G_{i, t}$ twice: the first time in a simple way, the second time the interaction term is additionally interacted with our variable of trust. Hence, $d_{i, t-1} * G D P_{-} G_{i, t}$ will capture the behavior of a (hypothetical) government with zero trust, while the interaction $d_{i, t-1} * G D P_{-} G_{i, t} *$ Trust $_{i, t-1}$ takes up the differential effect for governments with higher trust levels. If higher trust governments can afford to condition consolidation on macroeconomic suitability, we should expect a positive coefficient for interaction $d_{i, t-1} * G D P_{-} G_{i, t} *$ Trust $_{i, t-1}$, i.e. $\beta_{3}>0$. Conversely, $\beta_{2}$ may then be thought of as measuring the reaction of a country with zero trust which captures a hypothetical case as no country in our sample has a trust level of zero.

$\beta_{3}$, the coefficient of our three-way interaction term, is our main coefficient of interest, indicating whether governments enjoying a higher level of trust react differently from low 
trust governments, e.g. showing less consolidation in adverse macroeconomic situations and more in good times.

\section{Table 2: Summary statistics}

\begin{tabular}{|c|c|c|c|c|c|}
\hline \multicolumn{6}{|c|}{ Full sample (EU) } \\
\hline Variable & Observ. & Mean & S.D. & Min & Max \\
\hline Trust $_{i, t}$ & 269 & 0.421 & 0.158 & 0.090 & 0.786 \\
\hline$s_{i, t}$ & 269 & 0.009 & 0.063 & -0.280 & 0.264 \\
\hline$d_{i, t}$ & 269 & 0.593 & 0.309 & 0.061 & 1.700 \\
\hline$G D P_{-} G_{i, t}$ & 269 & -0.001 & 0.048 & -0.183 & 0.250 \\
\hline $\operatorname{Exp}_{i, t}$ & 269 & 0.000 & 0.019 & -0.054 & 0.161 \\
\hline \multicolumn{6}{|c|}{ Non-crisis sample (EU) } \\
\hline Variable & Observ. & Mean & S.D. & Min & Max \\
\hline Trust $_{i, t}$ & 189 & 0.443 & 0.148 & 0.136 & 0.778 \\
\hline$s_{i, t}$ & 189 & 0.023 & 0.055 & -0.060 & 0.249 \\
\hline$d_{i, t}$ & 189 & 0.568 & 0.298 & 0.061 & 1.257 \\
\hline$G D P_{-} G_{i, t}$ & 189 & 0.010 & 0.051 & -0.183 & 0.250 \\
\hline $\operatorname{Exp}_{i, t}$ & 189 & -0.004 & 0.015 & -0.054 & 0.044 \\
\hline \multicolumn{6}{|c|}{ Full sample (euro area) } \\
\hline Variable & Observ. & Mean & S.D. & Min & Max \\
\hline Trust $_{i, t}$ & 158 & 0.452 & 0.149 & 0.126 & 0.786 \\
\hline$s_{i, t}$ & 158 & 0.018 & 0.076 & -0.280 & 0.264 \\
\hline$d_{i, t}$ & 158 & 0.701 & 0.319 & 0.061 & 1.700 \\
\hline$G D P_{-} G_{i, t}$ & 158 & 0.000 & 0.034 & -0.133 & 0.133 \\
\hline $\operatorname{Exp}_{i, t}$ & 158 & 0.001 & 0.021 & -0.054 & 0.161 \\
\hline \multicolumn{6}{|c|}{ Non-crisis sample (euro area) } \\
\hline Variable & Observ. & Mean & S.D. & Min & Max \\
\hline Trust $_{i, t}$ & 111 & 0.477 & 0.134 & 0.227 & 0.778 \\
\hline$s_{i, t}$ & 111 & 0.034 & 0.065 & -0.060 & 0.249 \\
\hline$d_{i, t}$ & 111 & 0.666 & 0.311 & 0.061 & 1.257 \\
\hline$G D P_{-} G_{i, t}$ & 111 & 0.008 & 0.033 & -0.108 & 0.133 \\
\hline $\operatorname{Exp}_{i, t}$ & 111 & -0.004 & 0.016 & -0.054 & 0.044 \\
\hline
\end{tabular}

Notes: The table presents summary statistics for the macroeconomic variables and the average level of trust in national governments for the EU and the euro area. The non-crisis sample covers the years 1999 to 2008, while the full sample covers the years 1999 to 2011. GDP_G is measured as percentages of the trend figures, Exp in terms of GDP to account for country size heterogeneity. The shape of the unbalanced panel is determined by the data availability as indicated in Table 1.

An endogeneity problem may arise as high primary surpluses may increase trust. Therefore, we estimate equation (9) using lagged values of governments' level of trust. ${ }^{3}$

\footnotetext{
${ }^{3}$ Since Eurobarometer surveys related to trust in government are unavailable before 1999, lagged values imply somewhat smaller samples than those described in table 2.
} 
Table 2 contains the summary statistics. It corresponds to our regressions below by looking at the EU and euro area sample of countries and the years 1999-2011 and 1999-2008 separately. As is visible from figure 3, the development of debt was different in the subgroup of euro area countries and also the severity of the debt crisis may have been different. Therefore, table 3 reports four regressions using data samples that differ in two dimensions. Columns (A) and (B) use all EU countries, while columns (C) and (D) are based on euro area countries only. Columns (A) and (C) are based on years 1999-2011, while columns (B) and (D) exclude the crisis years 2009-2011.

Table 3: Fiscal reaction functions with lagged levels of government trust

\begin{tabular}{|c|c|c|c|c|}
\hline Variables & $\begin{array}{c}\text { (A) } \\
\text { EU, } \\
1999-2011\end{array}$ & $\begin{array}{l}\text { (B) } \\
\text { EU, } \\
\text { 1999-2008 }\end{array}$ & $\begin{array}{c}\text { imary Surplu } \\
\text { (C) } \\
\text { Euro area, } \\
\text { 1999-2011 }\end{array}$ & $\begin{array}{c}\text { (D) } \\
\text { Euro area, } \\
\text { 1999-2008 }\end{array}$ \\
\hline$\beta_{1}: d_{i, t-1}$ & $\begin{array}{l}0.035 \\
(0.87)\end{array}$ & $\begin{array}{l}0.122 * * \\
(2.31)\end{array}$ & $\begin{array}{l}0.085 * \\
(1.67)\end{array}$ & $\begin{array}{l}0.125 * \\
(1.91)\end{array}$ \\
\hline$\beta_{2}: d_{i, t-1} * G D P_{-} G_{i, t}$ & $\begin{array}{l}-0.377 \\
(-1.23)\end{array}$ & $\begin{array}{l}-1.400 * * * \\
(-2.87)\end{array}$ & $\begin{array}{l}-1.232 * \\
(-1.85)\end{array}$ & $\begin{array}{l}-1.415 * \\
(-1.97)\end{array}$ \\
\hline$\beta_{3}: d_{i, t-1} * G D P_{-} G_{i, t} * \operatorname{Trust}_{i, t-1}$ & $\begin{array}{l}1.444 \\
(1.54)\end{array}$ & $\begin{array}{l}3.008 * * * \\
(2.85)\end{array}$ & $\begin{array}{l}3.037 * * \\
(2.07)\end{array}$ & $\begin{array}{l}3.699 * * \\
(2.44)\end{array}$ \\
\hline$\beta_{4}: G D P_{-} G_{i, t}$ & $\begin{array}{l}0.350 * * * \\
(3.17)\end{array}$ & $\begin{array}{l}0.350 * * * \\
(3.00)\end{array}$ & $\begin{array}{l}1.466 * * \\
(2.42)\end{array}$ & $\begin{array}{l}0.327 \\
(0.91)\end{array}$ \\
\hline$\beta_{5}: G D P_{-} G_{i, t} *$ Trust $_{i, t-1}$ & $\begin{array}{l}-1.170 * * * \\
(-3.41)\end{array}$ & $\begin{array}{l}-1.188 * * * \\
(-3.57)\end{array}$ & $\begin{array}{l}-3.218 * * * \\
(-3.80)\end{array}$ & $\begin{array}{l}-1.534 * * * \\
(-2.89)\end{array}$ \\
\hline$\beta_{6}: d_{i, t-1} *$ Trust $_{i, t-1}$ & $\begin{array}{l}-0.040 \\
(-0.59)\end{array}$ & $\begin{array}{l}-0.149 * * \\
(-1.99)\end{array}$ & $\begin{array}{l}-0.003 \\
(-0.02)\end{array}$ & $\begin{array}{l}-0.030 \\
(-0.36)\end{array}$ \\
\hline$\beta_{7}:$ Trust $_{i, t-1}$ & $\begin{array}{l}0.057 \\
(1.40)\end{array}$ & $\begin{array}{l}0.096 * \\
(1.79)\end{array}$ & $\begin{array}{r}0.054 \\
(0.62)\end{array}$ & $\begin{array}{l}0.047 \\
(0.62)\end{array}$ \\
\hline$\beta_{8}: \operatorname{Exp}_{i, t}$ & $\begin{array}{l}-1.107 * * * \\
(-7.16)\end{array}$ & $\begin{array}{l}-0.762 * * * \\
(-6.14)\end{array}$ & $\begin{array}{l}-1.182 * * * \\
(-7.36)\end{array}$ & $\begin{array}{l}-0.968 * * * \\
(-5.91)\end{array}$ \\
\hline Country Fixed Effects & Yes & Yes & Yes & Yes \\
\hline Time Fixed Effects & Yes & $\begin{array}{r}\text { Yes } \\
0.94\end{array}$ & $\begin{array}{r}\text { Yes } \\
0.94\end{array}$ & $\begin{array}{l}\text { Yes } \\
0.96\end{array}$ \\
\hline Observations & 242 & 162 & 142 & 96 \\
\hline
\end{tabular}

Notes: Results are from OLS regressions with country and time fixed effects. t-statistics in parentheses are corrected for heteroscedasticity and autocorrelation. $* * *, * * *$ denote significance at $1 \%, 5 \%$, and $10 \%$, respectively. GDP_G and Exp are calculated from the cyclical components of the Hodrick-Prescott filter. $G D P_{-} G$ is measured as percentages of the trend figures, Exp in terms of GDP to account for country size heterogeneity. 
In general, exclusion of the crisis years results in a better fit. For countries that comply with the intertemporal budget constraint we should expect a positive reaction of the primary surplus upon an increase in debt. The overall marginal effect of $d_{i, t-1}$ is predicted to be positive by Proposition 1 (i). However, it is insufficient to look at the coefficient $\beta_{1}$ as $d_{i, t-1}$ appears in several interaction terms. If calculated accordingly, the marginal effect is positive for the four regressions $(0.020 ; 0.052 ; 0.086 ; 0.114)$ and significantly so in the case of samples (C) and (D). We also find that $\beta_{4}$ is positive, which indicates in line with Proposition 1 (ii) that primary surpluses are higher in years of above average growth, although the coefficient is insignificant in sample (D).

In all four regressions, our main coefficient of interest $\left(\beta_{3}\right)$ shows the expected positive sign which supports our hypothesis that trust in government helps a country to smooth consolidation efforts such that more of it happens in economic revivals (Proposition 1 (iii)). It is significant at the 1 or 5 percent levels in columns (B) - (D) and insignificant in column (A). To make sure that the results are not derived from an omission of variables that appear in interactions, we included the variables $G D P_{-} G_{i, t},\left(G D P_{-} G_{i, t} *\right.$ Trust $\left._{i, t-1}\right)$, $\left(d_{i, t-1} *\right.$ Trust $\left._{i, t-1}\right), \quad$ and Trust $_{i, t-1}$. The deviation of expenditures from the country trend has the expected negative impact on primary surplus in all equations.

The level of trust determined via surveys has been found to be strongly correlated with GDP growth (Stevenson and Wolfers, 2011). This may raise the concern that our results are based on a spurious correlation. In order to remove the cyclical behavior in our trust variable, we try two different specifications. In a first modification we use the country specific average level of trust in national governments. Hence, this alternative trust variable $\overline{\text { Trust }}_{i}$ shows variation across but not within countries and cannot be included along with country fixed effects; therefore the trust variable is only included in interaction terms. Table 4 presents the results derived from this time invariant trust measure. Again, we report on four different samples. Unlike in table 3, the new specification shows higher significance levels of coefficients for the longer samples in columns (A) and (C). Our main coefficient of interest $\left(\beta_{3}\right)$ is again always positive. It is statistically significant at the one percent level in (A) and 
(C), but insignificant in the shorter samples. Compared to table 3, the use of a country invariant trust measure tends to preserve the signs of the other covariates.

Table 4: Fiscal reaction functions with country averages of government trust

\begin{tabular}{|c|c|c|c|c|}
\hline Variables & $\begin{array}{c}\text { (A) } \\
\text { EU, } \\
1999-2011\end{array}$ & $\begin{array}{l}\text { endent Varial } \\
\text { (B) } \\
\text { EU, } \\
1999-2008 \\
\end{array}$ & $\begin{array}{l}\text { mary Surplus } \\
\text { (C) } \\
\text { Euro area, } \\
1999-2011\end{array}$ & $\begin{array}{c}(\mathrm{D}) \\
\text { Euro area, } \\
\text { 1999-2008 }\end{array}$ \\
\hline$\beta_{1}: d_{i, t-1}$ & $\begin{array}{l}-0.103 \\
(-1.12)\end{array}$ & $\begin{array}{l}0.325 * * \\
(2.28)\end{array}$ & $\begin{array}{l}-0.152 \\
(-0.99)\end{array}$ & $\begin{array}{l}0.335 \\
(1.48)\end{array}$ \\
\hline$\beta_{2}: d_{i, t-1} * G D P_{-} G_{i, t}$ & $\begin{array}{l}-1.288 * * * \\
(-2.92)\end{array}$ & $\begin{array}{l}-0.817 \\
(-1.50)\end{array}$ & $\begin{array}{l}-2.190 * * * \\
(-3.19)\end{array}$ & $\begin{array}{l}-0.764 \\
(-0.84)\end{array}$ \\
\hline$\beta_{3}: d_{i, t-1} * G D P_{-} G_{i, t} * \overline{\text { Trust }}_{i}$ & $\begin{array}{l}3.687 * * * \\
(3.28)\end{array}$ & $\begin{array}{l}1.714 \\
(1.43)\end{array}$ & $\begin{array}{l}5.801 \text { *** } \\
(3.60)\end{array}$ & $\begin{array}{l}1.782 \\
(0.95)\end{array}$ \\
\hline$\beta_{4}: G D P_{-} G_{i, t}$ & $\begin{array}{l}0.314 * * * \\
(3.03)\end{array}$ & $\begin{array}{l}0.204 * * \\
(2.19)\end{array}$ & $\begin{array}{l}0.969 \text { * } \\
(1.72)\end{array}$ & $\begin{array}{c}0.295 \\
(0.93)\end{array}$ \\
\hline$\beta_{5}: G D P_{-} G_{i, t} * \overline{\operatorname{Trust}}_{i}$ & $\begin{array}{l}-1.124 * * * \\
(-3.31)\end{array}$ & $\begin{array}{l}-0.719 * * * \\
(-2.70)\end{array}$ & $\begin{array}{l}-2.671 * * * \\
(-3.47)\end{array}$ & $\begin{array}{l}-1.194 * * \\
(-2.12)\end{array}$ \\
\hline$\beta_{6}: d_{i, t-1} * \overline{\text { Trust }}_{i}$ & $\begin{array}{l}0.295 \\
(1.38)\end{array}$ & $\begin{array}{l}-0.622 * * \\
(-2.09)\end{array}$ & $\begin{array}{r}0.549 \\
(1.42)\end{array}$ & $\begin{array}{l}-0.593 \\
(-1.19)\end{array}$ \\
\hline$\beta_{7}: \overline{\text { Trust }}_{i}$ & & & & \\
\hline$\beta_{8}: \operatorname{Exp}_{i, t}$ & $\begin{array}{l}-1.071 * * * \\
(-5.24)\end{array}$ & $\begin{array}{l}-0.618 * * * \\
(-6.44)\end{array}$ & $\begin{array}{l}-1.270 * * * \\
(-5.70)\end{array}$ & $\begin{array}{l}-0.753 * * * \\
(-4.57)\end{array}$ \\
\hline Country Fixed Effects & Yes & Yes & Yes & Yes \\
\hline Time Fixed Effects & Yes & Yes & Yes & Yes \\
\hline Adjusted $\mathrm{R}^{2}$ & 0.90 & 0.95 & 0.93 & 0.96 \\
\hline Observations & 269 & 189 & 158 & 111 \\
\hline
\end{tabular}

Notes: Results are from OLS regressions with country and time fixed effects. t-statistics in parentheses are based on standard errors corrected for heteroscedasticity and autocorrelation. $* * *, * * *$ denote significance at $1 \%, 5 \%$, and $10 \%$, respectively. GDP_G and Exp are calculated from the cyclical components of the Hodrick-Prescott filter. GDP_G is measured as percentages of the trend figures, Exp in terms of GDP to account for country size heterogeneity. The variable $\overline{\text { Trust }}_{i}$ is dropped due to its time invariance and inclusion of country fixed effects.

Another robustness check is based on the classification of countries into two groups: high trust or low trust countries. When a country has an average level of trust that is smaller than or equal to the respective EU or euro area average, the country is classified as being a low trust country and as a high trust country otherwise. Therefore, the trust variable is transformed into a dummy variable that may reduce measurement problems when comparing EU countries. For high trust countries the variable Trust $_{i}^{d}$ is encoded as a one. Results are found in table 5. Again we use an interaction term to find that high trust countries are less 
responsive to debt shocks compared to low trust countries if growth is low. The relevant coefficient is significantly positive in three out of the four samples used.

Table 5: Fiscal reaction functions with two trust groups

\begin{tabular}{|c|c|c|c|c|}
\hline Variables & $\begin{array}{c}(\mathrm{A}) \\
\mathrm{EU} \\
1999-2011\end{array}$ & $\begin{array}{c}\text { endent Varial } \\
\text { (B) } \\
\text { EU, } \\
\text { 1999-2008 }\end{array}$ & $\begin{array}{l}\text { mary Surplus/ } \\
\text { (C) } \\
\text { Euro area, } \\
\text { 1999-2011 }\end{array}$ & $\begin{array}{c}(\mathrm{D}) \\
\text { Euro area, } \\
1999-2008\end{array}$ \\
\hline$\beta_{1}: d_{i, t-1}$ & $\begin{array}{l}0.036 \\
(0.87)\end{array}$ & $\begin{array}{l}-0.034 \\
(-1.01)\end{array}$ & $\begin{array}{l}0.133 * \\
(1.92)\end{array}$ & $\begin{array}{l}0.103 \\
(1.59)\end{array}$ \\
\hline$\beta_{2}: d_{i, t-1} * G D P_{-} G_{i, t}$ & $\begin{array}{l}0.769 * * * \\
(2.61)\end{array}$ & $\begin{array}{l}0.009 \\
(0.07)\end{array}$ & $\begin{array}{l}2.138 * * * \\
(4.52)\end{array}$ & $\begin{array}{l}1.313 * * * \\
(4.10)\end{array}$ \\
\hline$\beta_{3}: d_{i, t-1} * G D P_{-} G_{i, t} * \operatorname{Trust}_{i}^{d}$ & $\begin{array}{l}0.795 * * \\
(2.58)\end{array}$ & $\begin{array}{l}-0.114 \\
(-0.56)\end{array}$ & $\begin{array}{l}2.129 * * * \\
(4.11)\end{array}$ & $\begin{array}{l}1.335 * * * \\
(4.04)\end{array}$ \\
\hline$\beta_{4}: G D P_{-} G_{i, t}$ & $\begin{array}{l}-0.275 * * * \\
(-2.68)\end{array}$ & $\begin{array}{l}-0.129 * * \\
(-2.22)\end{array}$ & $\begin{array}{l}-0.968 * * * \\
(-4.56)\end{array}$ & $\begin{array}{l}-0.641 * * * \\
(-4.89)\end{array}$ \\
\hline$\beta_{5}: G D P_{-} G_{i, t} *$ Trust $_{i}^{d}$ & $\begin{array}{l}-0.280 * * * \\
(-2.59)\end{array}$ & $\begin{array}{l}-0.073 \\
(-1.18)\end{array}$ & $\begin{array}{l}-0.891 * * * \\
(-2.82)\end{array}$ & $\begin{array}{l}-0.409 * * * \\
(-2.82)\end{array}$ \\
\hline$\beta_{6}: d_{i, t-1} * \operatorname{Trust}_{i}^{d}$ & $\begin{array}{l}0.028 \\
(0.45)\end{array}$ & $\begin{array}{l}-0.196 * * * \\
(-2.74)\end{array}$ & $\begin{array}{r}0.080 \\
(1.07)\end{array}$ & $\begin{array}{l}-0.003 \\
(-0.05)\end{array}$ \\
\hline$\beta_{7}:$ Trust $_{i}^{d}$ & & & & \\
\hline$\beta_{8}: \operatorname{Exp}_{i, t}$ & $\begin{array}{l}-0.989 * * * \\
(-4.66)\end{array}$ & $\begin{array}{l}-0.610 * * * \\
(-5.27)\end{array}$ & $\begin{array}{l}-1.296 * * * \\
(-5.57)\end{array}$ & $\begin{array}{l}-0.798 * * * \\
(-5.02)\end{array}$ \\
\hline Country Fixed Effects & Yes & Yes & Yes & Yes \\
\hline Time Fixed Effects & Yes & Yes & Yes & Yes \\
\hline Adjusted $\mathrm{R}^{2}$ & 0.90 & 0.94 & 0.93 & 0.97 \\
\hline Observations & 269 & 189 & 158 & 111 \\
\hline
\end{tabular}

Notes: Results are from OLS regressions with country and time fixed effects. t-statistics in parentheses are based on standard errors corrected for heteroscedasticity and autocorrelation. $* * * * * *$, denote significance at $1 \%, 5 \%$, and $10 \%$, respectively. GDP_G and Exp are calculated from the cyclical components of the Hodrick-Prescott filter. GDP_G is measured as percentages of the trend figures, Exp in terms of GDP to account for country size heterogeneity. The variable Trust $_{i}^{d}$ is dropped due to its time invariance and inclusion of country fixed effects. 


\section{Conclusion}

The European debt crisis has triggered a renewed interest in the possible contractionary effects of fiscal consolidation and many recent papers empirically discuss this issue. The present paper looks at a related issue by asking about the determinants of fiscal consolidation efforts as reflected in the primary surplus of countries. Our conjecture is that governments will usually find it more attractive to consolidate in a situation of relatively high growth, but based on a simple stylized model of government behavior the expectation is that mainly high trust governments will be in a position to defer consolidation to a period with higher growth. Overall, evidence on European countries provides support for this expectation. Fiscal reaction functions of high and low trust governments seem to differ in this respect.

A recent literature looks at differences of business cycles across countries and finds that well governed countries tend to have less pronounced fluctuations (Altug and Canova, 2012). The present paper may be seen in connection to this observation as it highlights a possible transmission channel. Good governance and high trust in government seem to allow for fiscal policies that are more counter-cyclical and lead to less fiscal corrections in times when growth is low. 


\section{Appendix}

We combine a selected set of 24 Eurobarometer surveys which include our main variable of interest "Trust in the National Government". The surveys are conducted on a semi-annual basis and are obtained from the "GESIS-Leibniz-Institute for the Social Sciences" in Cologne, Germany.

Table 6: Eurobarometer surveys used

\begin{tabular}{llll}
\hline \hline Study Number & Title & Year & Version \\
\hline ZA 5567 & Eurobarometer 76.3 & 2011 & $1.0 .0,17.09 .2012$, doi:10.4232/1.11448 \\
\hline ZA 5481 & Eurobarometer 75.3 & 2011 & $1.0 .0,01.09 .2012$, doi:10.4232/1.10768 \\
\hline ZA 5449 & Eurobarometer 74.2 & 2010 & $1.1 .0,08.06 .2011$, doi:10.4232/1.10707 \\
\hline ZA 5234 & Eurobarometer 73.4 & 2010 & $1.0 .0,23.11 .2010$, doi:10.4232/1.10197 \\
\hline ZA 4994 & Eurobarometer 72.4 & 2009 & $3.0 .0,03.02 .2012$, doi:10.4232/1.11141 \\
\hline ZA 4973 & Eurobarometer 71.3 & 2009 & $3.0 .0,03.02 .2012$, doi:10.4232/1.11135 \\
\hline ZA 4819 & Eurobarometer 70.1 & 2008 & $3.0 .1,17.11 .2010$, doi:10.4232/1.10193 \\
\hline ZA 4744 & Eurobarometer 69.2 & 2008 & $4.0 .0,18.10 .2011$, doi:10.4232/1.10992 \\
\hline ZA 4565 & Eurobarometer 68.1 & 2007 & $4.0 .0,09.09 .2010$, doi:10.4232/1.10126 \\
\hline ZA 4530 & Eurobarometer 67.2 & 2007 & $2.0 .0,18.12 .2009$, doi:10.4232/1.10068 \\
\hline ZA 4526 & Eurobarometer 66.1 & 2006 & $1.0 .0,13.04 .2010$, doi:10.4232/1.4526 \\
\hline ZA 4506 & Eurobarometer 65.2 & 2006 & $1.0 .0,13.04 .2010$, doi:10.4232/1.4506 \\
\hline ZA 4414 & Eurobarometer 64.2 & 2005 & $1.0 .0,13.04 .2010$, doi:10.4232/1.4414 \\
\hline ZA 4411 & Eurobarometer 63.4 & 2005 & $1.0 .0,13.04 .2010$, doi:10.4232/1.4411 \\
\hline ZA 4229 & Eurobarometer 62.0 & 2004 & $1.0 .0,13.04 .2010$, doi:10.4232/1.4229 \\
\hline ZA 4056 & Eurobarometer 61.0 & 2004 & $1.0 .0,13.04 .2010$, doi:10.4232/1.4056 \\
\hline ZA 3938 & Eurobarometer 60.1 & 2003 & $1.0 .0,13.04 .2010$, doi:10.4232/1.3938 \\
\hline ZA 3904 & Eurobarometer 59.1 & 2003 & $1.0 .0,13.04 .2010$, doi:10.4232/1.3904 \\
\hline ZA 3693 & Eurobarometer 58.1 & 2002 & $1.0 .0,13.04 .2010$, doi:10.4232/1.3693 \\
\hline ZA 3639 & Eurobarometer 57.1 & 2002 & $1.0 .0,13.04 .2010$, doi:10.4232/1.3639 \\
\hline ZA 3627 & Eurobarometer 56.2 & 2001 & $1.0 .0,13.04 .2010$, doi:10.4232/1.3627 \\
\hline ZA 3507 & Eurobarometer 55.1 & 2001 & $1.0 .0,13.04 .2010$, doi:10.4232/1.3507 \\
\hline ZA 3204 & Eurobarometer 52.0 & 1999 & $1.0 .0,13.04 .2010$, doi:10.4232/1.3204 \\
\hline ZA 3171 & Eurobarometer 51.0 & 1999 & $1.0 .0,13.04 .2010$, doi:10.4232/1.3171 \\
\hline \hline
\end{tabular}




\section{References}

Alesina, A., and E. La Ferrara (2002), “Who trusts others?", Journal of Public Economics 85, 207-234.

Altug, S., and F. Canova (2012), "Do institutions and culture matter for business cycles?", Koç University, Working Paper.

Auerbach, A. J., and Y. Gorodnichenko (2012a), "Fiscal multipliers in recession and expansion", in: "Fiscal policy after the financial crisis", in: Alesina, A., and F. Giavazzi (eds.), Chicago, University of Chicago Press.

Auerbach, A. J., and Y. Gorodnichenko (2012b), "Measuring the output responses to fiscal policy", American Economic Journal: Economic Policy 4, 1-27.

Barro, R., and D. Gordon (1983), "Rules, discretion and reputation in a model of monetary policy", Journal of Monetary Economics 12, 101-122.

Bohn, H. (1998), "The behavior of U.S. public debt and deficits", Quarterly Journal of Economics 113, 949-963.

Bursian, D., and E. Faia (2013), "Trust in the monetary authority", SAFE Working Paper 14.

Bursian, D., and S. Fürth (2012), "Trust me! I am a European Central Banker", Goethe University Frankfurt, Working Paper.

Feld, L., and B. Frey (2002), "Trust breeds trust: How taxpayers are treated", Economics of Governance 3, 87-99.

Hakkio, C., and M. Rush (1991), "Is the budget deficit "too large?"”, Economic Inquiry 29, $429-445$.

Haug, A. (1990), "Cointegration and government borrowing constraints: Evidence for the United States", Journal of Business and Economic Statistics 9, 97-101.

Heinemann, F., and T. Hennighausen (2012), "Understanding public-debt preferences", FinanzArchiv/Public Finance Analysis 68, 406-430.

Hilsenrath, J. (2013), "How a trust deficit is hurting the economy", Wall Street Journal (Europe Edition), 27 January 2013, http://online.wsj.com/article/SB10001424127887323854904578264161278400462.html.

Knack, S., and P. Keefer (1997), "Does social capital have an economic payoff? A crosscountry investigation", Quarterly Journal of Economics 112, 1251-1288.

Kremers, J. (1989), "U.S. federal indebtedness and the conduct of fiscal policy", Journal of Monetary Economics 23, 219-238.

Kydland, E., and E. C. Prescott (1977), "Rules rather than discretion: The inconsistency of optimal plans", Journal of Political Economy 85, 473-491.

La Porta, R., F. Lopez-de-Silanes, A. Shleifer, and R. Vishny (1997), “Trust in large organizations", American Economic Review 87, 333-338.

Mendoza, E. G., and J. D. Ostry (2008), "International evidence on fiscal solvency: Is fiscal policy 'responsible'?", Journal of Monetary Economics 55, 1081-1093.

Rogoff, K. (1985), "The optimal degree of commitment to an intermediate target", Quarterly Journal of Economics 100, 1169-1190.

Sapienza, P., and L. Zingales (2011), "Trust and finance", NBER Reporter 2, 16-19.

Stevenson, B., and J. Wolfers (2011), "Trust in public institutions over the business cycle", American Economic Review 101, 281-287. 
Trehan, B., and C. Walsh (1991), "Testing intertemporal budget constraints: Theory and applications to U.S. federal budget and current account deficits", Journal of Money, Credit and Banking 23, 206-223.

Wilcox, D. (1989), “The sustainability of government deficits: Implications of the presentvalue borrowing constraint", Journal of Money, Credit and Banking 21, 291-306.

Zak, P., and S. Knack (1999), “Trust and growth”, Economic Journal 111, 295-321. 